\title{
From Consistency to Coherence
}

Whitehead's Transformation of James's Epistemic Conservatism

\section{Dennis Soelch}

\section{(2) OpenEdition}

Electronic version

URL: http://journals.openedition.org/ejpap/870

DOI: 10.4000/ejpap.870

ISSN: 2036-4091

\section{Publisher}

Associazione Pragma

Electronic reference

Dennis Soelch, «From Consistency to Coherence », European Journal of Pragmatism and American Philosophy [Online], III-1 | 2011, Online since 01 July 2011, connection on 20 April 2019. URL : http:// journals.openedition.org/ejpap/870 ; DOI : 10.4000/ejpap.870

This text was automatically generated on 20 April 2019.

\section{c) (i)}

Author retains copyright and grants the European Journal of Pragmatism and American Philosophy right of first publication with the work simultaneously licensed under a Creative Commons AttributionNonCommercial-NoDerivatives 4.0 International License. 


\title{
From Consistency to Coherence
}

Whitehead's Transformation of James's Epistemic Conservatism

\author{
Dennis Soelch
}

\section{Introduction}

1 What pragmatism is, whether it refers to a philosophical method, a specific theory, cultural politics, a literary theory or a mixture of all of these, has been part of the controversy surrounding pragmatism from its very beginning. Accordingly, there seem to be as many names for the movement as there are thinkers, which becomes most explicitly manifest in Peirce's famous abandonment of the term "pragmatism" in favour of "pragmaticism." The genealogy of pragmatism, however, has hardly ever been questioned. The classical period or first generation of pragmatism consists of Charles Sanders Peirce, William James, John Dewey, Ferdinand C. S. Schiller and, on its legal and sociological side, Oliver Wendell Holmes and George Herbert Mead. Contemporary pragmatism or the second generation comprises at least three major strands which can be subsumed under the headings of cultural pragmatism, analytic pragmatism and continental pragmatism. Pragmatism as cultural politics is usually regarded to revolve around Richard Rorty, while prominent representatives of analytic pragmatism include Willard Van Orman Quine, Hilary Putnam, and Nicholas Rescher. Although less commonly used, the denomination of continental pragmatism is often employed to refer to the writings of Karl-Otto Apel and Juergen Habermas. But not-withstanding the fact that the list of canonical neo-pragmatists has grown extensively, there is widespread agreement as to who falls within the pragmatist tradition and who does not. One of the most significant thinkers in the wake of William James, however, whose work can and must be regarded as a major contribution to pragmatist thinking, has so far been unduly neglected. Although Alfred North Whitehead is not counted among the pragmatists, his work not only helps to bridge the gap between American and European philosophy, but at the same time links classical pragmatism with its contemporary, more analytic versions. This development can best be illustrated by reference to the respective methodologies 
and theories of truth. James, I shall argue, advances a specific form of epistemic conservatism which modifies the pragmatic concept of a proposition's or theory's applicability in order to avoid a separation of experience into isolated, discontinuous fields of knowledge. The Jamesian theory of knowledge comprises both an empirical dimension that gets manifest in the notion of an idea's "cash-value," ${ }^{1}$ and a rational or subjective dimension succinctly expressed in the notion of "consistency." ${ }^{2}$ This twofold conception is spelled out and elaborated on in Whitehead's most systematic philosophical work Process and Reality. Profoundly influenced by James' philosophy, Whitehead's project of devising a speculative cosmology based on a pragmatic methodology introduces a number of criteria that allow him to offer a more refined, systematic theory of knowledge. Most significantly, the criterion of consistency is replaced by that of coherence and supplemented by the demand for logic in order to ensure a comprehensive, unified theory. Although limited in scope to a metaphysical description of the world, this form of speculative pragmatism avoids the common charges often levelled against James.

2 Whitehead, I will argue in this paper, is methodologically a pragmatist in the Jamesian sense of the term. A re-assessment of his philosophy with particular focus on its pragmatic methodology requires us to elaborate the intriguing relationship between the two thinkers. Hence, in a first step I will follow some of the various traces of James' thought in Whitehead's oeuvre to allow for an estimate of the degree of James' influence. Despite the fact that Whitehead's perspective on the history of philosophy poses a serious challenge to interpreters and almost makes impossible a clear account of how far his thought falls within a certain tradition, there is evidence to suggest that James played a major role in his philosophical development. In fact Whitehead's appreciation of James does not only concern the critique of consciousness as a substance and the turn towards a functionalist psychology, but also, on a much more fundamental level, James' methodology. Hence, I will in a second step reconstruct the Jamesian understanding of pragmatism as both a method and a theory of truth with particular focus on the concept of consistency. On this basis it will then be possible to outline the Whiteheadian approach and to re-assess his place with the philosophical tradition, before pointing out the differences between the two conceptions by dint of the aspect of religious experience. Finally, I will give an outlook as to the development of pragmatism from James to contemporary trends via Whitehead as a linking figure.

\section{James, Whitehead and the American Renaissance}

3 For every philosopher it is possible to find another one who praises him as a genius, a trailblazer and precursor of his own thinking. In some cases, however, this admiration comes somewhat as a surprise, because the respective types of thought seem to differ more than they seem to agree. This is particularly so with the philosophies of William James and Alfred North Whitehead. The former is known as a public intellectual, skeptical about logic as a reliable tool of metaphysical enquiry, his writings vividly concrete and sometimes almost as intimate as a confession. The latter, on the contrary, is renowned for being a brilliant mathematician who spent a decade trying to rebuild the foundations of logic and whose major work is a masterpiece of complex abstractions. Hence, when Whitehead attributes to James "the inauguration of a new stage in philosophy"3 and 
stylizes him as the central figure in the foundation of the American Renaissance, ${ }^{4}$ some elaboration and clarification is required.

4 James had died in 1910, fourteen years before Whitehead's arrival in New England. It is highly probable that Whitehead had already taken to perusing James' works while still being a professor of mathematics in London and that he was familiar with pragmatist thinking prior to settling in his adopted country. As early as in 1898, when he was working on his Treatise on Universal Algebra, he mentioned the contributions to logic and symbolization made by Peirce, whom he would later name in one breath with James. The first explicit reference to James dates back to 1910, when the reader of Whitehead's entry on "Mathematics" in the Encyclopedia Britannica is referred to James' Pragmatism for further reading on the question of "the one and the many." ${ }^{5}$ Beginning with his transition to Harvard in 1924 - "the university of William James" - the American becomes omnipresent in his writings. Considering the fact that Whitehead took up his enormously productive philosophical task almost immediately after his arrival, it is difficult to imagine that he should not have been well acquainted with James' philosophy by the time he started teaching and writing on philosophy. This is supported by Whitehead's habit of ranking James as a matter of course among the philosophical classics, together with Plato,

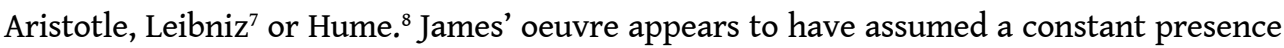
in Whitehead's thought, so that a quotation must "of course" ${ }^{9}$ be borrowed from William James.

One of the most significant passages for Whitehead's deep appreciation of James stands out in a letter written to Charles Hartshorne in 1936. Whitehead refers to Charles Peirce and William James as "the effective founders of the American Renaissance," ${ }^{10}$ while at the same time comparing Peirce to Aristotle and James to Plato. Certainly a comparison to Plato is "the highest possible Whiteheadian praise." ${ }^{11}$ But at the same time the reversal of the actual chronology stresses a central aspect of Whitehead's own philosophical credo: The close link to the logic of science in Peirce's pragmatism is seen as an analogy to Aristotle's systematization and limitation of Plato's wide range of thinking. Hence, the analogy is not simply a form of praise and approval, but indicates Whitehead's preference for the Jamesian approach that transcends the positivistic boundaries of scientifically analyzable phenomena. This is not least obvious in the continuation and criticism of James' Varieties of Religious Experience in his own study Religion in the Making, which reveals Whitehead as a close and attentive reader of James, whose non-sensualistic concept of experience he embraces. Next to William James, Whitehead is one of the first thinkers of the 20th century to approach religion by way of an appreciation of its factual givenness as an existential and cultural phenomenon.

6 Although the two never met personally, the lasting impact of James's work on Whitehead is one of the most fascinating and challenging in 20th century philosophy. Craig R. Eisendrath was one of the first to come to the conclusion that Whitehead spells out the systematic account James himself never produced. ${ }^{12}$ More recently, Michel Weber ${ }^{13}$ and Scott Sinclair ${ }^{14}$ have elaborated on the relation between James and Whitehead, shedding light on common motifs and shared approaches to the concepts of time, feeling, consciousness and religion. Thus, it is all the more surprising that the "developmental relation to pragmatism" 15 in Whitehead has not yet been made the object of a detailed study. His pragmatic background is already tangible in some of the early essays published as The Aims of Education in 1929, where he develops a pragmatist approach to epistemology and even semantics ${ }^{16}$ which to a certain extent anticipates the more 
elaborate findings of the late Wittgenstein. Although he does not explicitly engage in the discourse on classical pragmatist conceptions, the notion of pragmatism continuously reappears in all his major writings. With regard to science, religion and philosophy Whitehead appeals to the "pragmatic test," concluding in the identification of pragmatism and that "self-evidence, which sustains itself in civilized experience," ${ }^{17}$ thus putting philosophy as a whole on a pragmatic basis. In the present paper I will restrict myself to Whitehead's contribution to pragmatism in the context of philosophical cosmology, mainly focusing on his magnum opus Process and Reality.

\section{Consistency and James' Theory of Truth}

7 James defines pragmatism as both a philosophical method and a theory of truth ${ }^{18}$ and both aspects overlap and support each other. Taking up Peirce's idea to bridge the gap between res and intellectus through human action, James refuses to regard truth as the stagnant isomorphic relation Rorty has referred to as a mirror of nature. A notion or concept does not require a trans-empirical quality to be able to direct us to experiential reality. Within a radically empiricist world ontologically only definable as experience, the criteria for a concept's truth value must itself be experiential, i.e. the core of a true idea is its function of successful guidance.

8 Truth must not be isolated from actual experience, and all instances of hypothetic scientific truth ultimately rest on particular practical experience in the widest sense of the term. For James, truth is a gradual concept, whose cash-value depends on how well it serves to guide us to new experiences. It is, moreover, a processual concept, since the truth of a proposition is not a definite quality to be revealed in the course of its practical application, but refers to the continuous adaption of a human agent to a world of stubborn facts. Verification as the final confirmation of a proposition's a-temporal truth value is impossible, first of all because that would presuppose a universe dominated by consistent principles - an ontological premise James explicitly refutes ${ }^{19}$ - and second of all because final verification would require an objective perspective which is never given in a world of subjective experience. Hypotheses can only be true conditionally and might eventually be falsified.

9 The pragmatic theory of truth is anticipated as early as in James' Principles of Psychology, in which the idea of Humean atomistic impressions is boldly refuted. Relations between objects of perception and cognition are not external and to be construed according to the laws of logic, but are directly apprehended. "Let us use the words psychic overtone, suffusion, or fringe, to designate the influence of a faint brain-process upon our thought, as it makes it aware of relations and objects but dimly perceived." ${ }^{20}$ Connections between sensually perceived phenomena are included and transmitted in ordinary perception, although they are not apprehended as distinct objects. The classical, Thomistic theory of truth, which is built on the idea of an isomorphic representation of things in the mind, is unable to explain our awareness of the relatedness of events and objects. Instead of mirroring isolated sense-data, concepts are "purely teleological weapons of the mind."21 Pragmatism elaborates on this specific teleology of concepts, and while in the Principles the external, or rather experiential, world is regarded as delivering relations in the form of diffuse sensations, James' later writings focus on the converse relationship. "To 'agree' in the widest sense with a reality, can only mean to be guided either straight up to it or into its surroundings, or to be put into such working touch with it as to handle either it or something 
connected with it better than if we disagreed." 22 If truth cannot consist in an exact copy of reality, true ideas or beliefs are characterized by their teleological content, which allow for a successful orientation among experiential relations, i.e. orientation in the empirical world. Truth is not a property inherent in specific ideas and independent of being tested against the world of stubborn facts and which beliefs may count as true beliefs turns out in the process of their application. Truth thus becomes an experiential concept that is subject to empirical, though by no means positivistic, testing.

However, apart from the empirical dimension usually associated with a pragmatist conception of truth, the Jamesian approach comprises a rational dimension that is introduced under the heading of consistency. It is not only the establishment of a successful relation to the experiential world that is satisfactory, but also the agreement between newly found ideas, propositions, theories with those already accepted as true. "Above all, we find consistency satisfactory, consistency between the present idea and the rest of our mental equipment, including the whole order of our sensations, and that of our intuitions of likeness and difference, and our whole stock of previously acquired truths." ${ }^{23}$ The demand that new theories be consistent with older ones is probably the decisive rational criterion in James' pragmatist conception of truth, although it is hardly ever appreciated in its full significance. Consistency ensures unity of experience in the face of an inescapable epistemic pluralism that results from the fact that concepts as teleological instruments are always employed to serve individual interests.

11 This subjective dimension of the Jamesian theory of truth can be characterised as a form of epistemic conservatism that can neither be classed among the foundationalist theories of knowledge nor among those generally referred to as coherence theories. Epistemic conservatism does by no means denote a unified position or clearly defined concept, but has come to stand for a variety of different epistemological theories. ${ }^{24}$ In its most naïve formulation it states that "the fact that a person believes a proposition [is] at least a prima facie epistemic reason in support of the proposition believed." ${ }^{25}$ It would take us too far to enlarge on the intricacies of the current debate concerning the epistemic value of internal states. It will suffice at this point to bear in mind that all versions of epistemic conservatism share the assumption that the fact that an agent holds a certain belief plays a major role in the agent being justified in having this belief. James' argument, if I understand him correctly, functions on three different levels, namely on a psychological, an ontological and a pragmatic one.

In matters of belief, James states, "we are all extreme conservatives." ${ }^{26}$ This is what I will call his psychological argument for epistemic conservatism. James's version of pragmatism, in contrast to Peirce's and even to Dewey's, highlights the importance of the subjective, individual genesis of truths. With regard to their beliefs, people just find it enormously difficult to give up deeply rooted convictions, and concepts that have stood the test of applicability function as a criterion for the evaluation of novel ideas. Percepts, concepts and theories alike are affected and need to find a place within a coherent scheme, before they can be accepted as true. A prominent example for the demand for this form of consistency is the discovery of radium, whose radiation and energy production seemed to contradict the law of the conservation of energy, until measurement and law of nature were "re-married" through the concept of selftransforming atomic nuclei; a process in scientific activity that was to repeat itself decades later in the postulation of anti-neutrinos to explain the energy balance of beta radiation. 
13 of possible discoveries and experiences, but is a psychological demand that bears postponement. As long as a belief is constitutive for its own verification, such as the belief in my ability to jump across an abyss, it would be irrational to abandon my belief ex ante, just because it is not consistent with other beliefs. It is only in moments of reflection that potential contradictions within the field of my beliefs show and result in an "inward trouble." ${ }^{27}$ This is particularly significant with regard to religious phenomena as discussed in The Will to Believe and the Varieties of Religious Experience: We are justified in considering a proposition to be true for subjective reasons, if a decision is existential and cannot be put off. But even if such a belief is prima facie justified, its cognitive content must allow a comparison with other beliefs - after all the crucial point for James in that respect is that the acceptance of a hypothesis on pragmatic, external grounds enables us to achieve the particular evidence required. Its truth value is a relative one, whose particular use earns it an advance of trust, which, however, must maintain itself at least in the rational process of making our ideas cohere. "New truth is always a smoother-over of transitions. It marries old opinion to new fact so as ever to show a minimum of jolt, a maximum of continuity." ${ }^{28}$ Ultimately the subjective starting point decides which truths make up the core of beliefs. As new experiences have to stand the test against the organic whole of individually accepted beliefs, impressive religious experiences made early in the personal biography will in most cases result in a more are less religious worldview. Complete consistency is a limit-concept, which is in effect never achieved, but which guides the formulation of comprehensive theories.

The second dimension of James' epistemic conservatism is not, like the psychological one, restricted to saying that we actually are conservative when it comes to modifying existing beliefs, but holds that consistency with what we already believe is a necessary condition for a belief to be acceptable as true. Genealogical consistency of beliefs systematically corresponds to the coherence of the individual components of our body of theoretical knowledge, and apart from the psychological thesis, James advocates a specific form of coherentism. ${ }^{29}$ Epistemic externalists arguing against epistemic conservatism or coherentism usually pose the question, why the fact that different beliefs do not contradict one another should be a criterion for the truth of each of the individual beliefs. James's answer refers back to his experiential ontology. From a radically empiricist point of view the stock of previously acquired truths is itself part of experience, which a pragmatically interpreted correspondence theory of truth must take into account. Intellectual satisfactions are "all mere matters of consistency - and emphatically not of consistency between an absolute reality and the mind's copies of it, but actually felt consistency among judgments, objects, and habits of reacting, in the mind's own experienceable world." ${ }^{30}$ If reality can only be described as experience, and our old beliefs, our commonsense, and even our language form part of the stream of experience there is no alternative to considering all beliefs as necessary criterion to judge whether a belief is true or false. At the same time it is clear that James epistemic conservatism does not issue in a holistic coherentism, but in a conception that allows for a gradation of a pluralism of truths. The more satisfactory relations between different experiences a hypothesis generates, i.e. the greater the sum of satisfactions it produces, the 'truer' it is. 31

The third dimension of James' epistemic conservatism is based on a purely pragmatic argument. To a certain extent it runs vertically to the epistemological argument of a 
coherence theory of truth, because it prima facie allows for individual, isolated propositions or ideas to be true. The function of "satisfactory working or leading" ${ }^{32}$ in James is a conjunctive criterion for truth, in which objectivity and subjectivity are synthesized to constitute truth relations in the framework of our experience. But methodologically James clearly differentiates between the psychological and the empirical aspect: "We live in a world of realities that can be infinitely harmful. Ideas that tell us which of them to expect count as true ideas in all this primary sphere of verification, and the pursuit of such ideas is a primary human duty. ${ }^{\prime 3}$ The endeavour to achieve consistency between the individual propositions is secondary to the genesis of empirically successful concepts. It is only when a notion or a concept has proven its cashvalue that the necessity arises to demand consistency. This differentiation is entirely in accordance with James's emphasis on the inertia of existing truths: A novel idea, which contradicts established concepts, will only gradually become accepted and will be considerably modified in the course of its integration. As long as the hitherto isolated proposition is not successfully applicable to the experienced reality, the criterion of consistency is prima facie insignificant. Such a purely instrumental conception of truth, however, would face the problem of admitting discontinuous theories which approach different fields of experience by means of different concepts, thus undermining James's intention of equally doing justice to science, religion and morality. The danger of a separation of theories, each of which might be successful in its own subject area, might issue into a competitive struggle for supremacy, which in the twentieth century almost seemed to have been won by the causal explanations of the natural sciences. Principally, as even Rorty acknowledges, "scientific inquiry is best viewed as the attempt to find a single, unified, coherent description of the world." ${ }^{34}$ While Rorty attempts to exclude religious experience from a unified philosophical theory in order to privatize and depoliticize it, James aims at the inclusion of all the diverse dimensions of experience. Consistency is necessary, because only when no field of experience is privileged can we ensure that the possible scope of novel experience does not become limited and restricted.

16 It is on the basis of this conception that James' pragmatism can be defended against the common charges leveled most prominently by Bertrand Russell and, more recently, by Nicholas Rescher, according to whom the Jamesian focus on affective, subjective satisfaction brings with it the danger of their "disassembling into a virtually endless proliferation of purposive contextualizations." ${ }^{35}$ It is often neglected that intersubjectivity does play a significant role in James' philosophy. Already in the Varieties does he point to the fact that a religious belief - as well as a scientific theory - is philosophically unsatisfactory, if it excludes a large part of our experience. God or the divine is experienced individually, but it is experienced as something that has objective reality and is related to the rest of the universe. A purely private God is not a God we want to believe in. Rorty's argument that at least religiously inspired belief is immune from confirmation and coherence, because it is not subject to intersubjective standards, ${ }^{36}$ neglects the fact that relevant beliefs are always susceptible to rational critique. As an intellectually sincere person I cannot avoid accepting the criteria of rationality of my fellows to such a degree that a merely privately held hope for a transcendent power will in most cases not pass the comparison with other beliefs. "[T] he greatest enemy of any of our truths may be the rest of our truths," ${ }^{37}$ and one of the truths consists in accepting divergent beliefs in other individuals as one experience in our own coherent system of beliefs. As implied in the notion of the cash-value, ${ }^{38}$ the satisfactoriness of truth oscillates 
between individual and public as much as money is only valuable in a social setting. Each individual's experience, like its ideals or moral convictions, always represents a partial segment of the totality of experience. At least as philosophers, who are aware of the fact that their experience might not be historically and culturally representative, we need to "throw in our own spontaneous ideals, even the dearest, impartially in with that total mass of ideas which are fairly to be judged." ${ }^{{ }^{39}}$ Rationality might not mandate that we have our beliefs tested by others, but we do at least need to consider alternative beliefs and integrate the fact that these other, potentially conflicting beliefs exist into our personal coherent scheme. Intersubjectivity is not a prioritized criterion in James, but starting from the idea of consistency it is obvious that intersubjectivity enters into each subjectively structured totality of experience.

\section{Whitehead's Transformation of James' Theory of Truth}

17 James's approach to truth anticipates a methodological enterprise that finds its most concise formulation in the philosophy of Alfred $\mathrm{N}$. Whitehead, the pragmatic character of which has escaped the attention of critics. At the beginning of Process and Reality Whitehead outlines the task and the method of his so-called speculative philosophy. "Speculative Philosophy is the endeavour to frame a coherent, logical, necessary system of general ideas in terms of which every element of our experience can be interpreted. By this notion of 'interpretation' I mean that everything of which we are conscious, as enjoyed, perceived, willed, or thought, shall have the character of a particular instance of the general scheme." ${ }^{\prime 40}$ The idea of the necessity of a cosmological scheme is then elaborated on as meaning the applicability and adequacy of the basic metaphysical concepts. A notion is applicable if there is at least one item of experience which is thus interpretable, and it is adequate, if the entire texture of human experience is capable of such interpretation. Both aspects taken together form the "empirical side" ${ }^{41}$ of Whitehead's speculative philosophy, while logic and coherence constitute its rational side. Translated into Jamesian terms, the applicability of a concept consists in its experiential satisfactoriness. The pragmatic methodology underlying Whitehead's project of devising a philosophical cosmology starts from a level different from sensory perception and individual experience, as metaphysics is based on the data of the sciences and civilized experience as manifest in language, conduct, literature and art. In that sense, it is first of all the individual sciences that proceed pragmatically by developing notions and experimentally testing their working value. ${ }^{42}$ Metaphysics then is pragmatism functioning of the level of the philosophy of science, with the purpose of revising the sciences' terminological and methodological presuppositions. The function of coordinating the sciences is guided by the hope that their results might eventually result in one all-encompassing system. Accordingly, metaphysics means a systematic account of everything that can be experienced and thought about on the basis of the coordinated assumption of every other theoretic inquiry. ${ }^{43}$ "Whatever is found in 'practice' must lie within the scope of the metaphysical description" 44 and the "pragmatic test" 45 to be passed by a philosophical cosmology is whether every instance of experience can be interpreted by recourse to its notions.

18 At a first glance the concept of adequacy seems to contain and make redundant that of applicability. The distinction between a sufficient and a necessary condition, however, 
does not simply reflect the cosmological system aimed at, but the mode of procedure. ${ }^{46}$ The metaphysical enquiry starts by interpreting one specific field of human experience in order to ensure the applicability of the abstract scheme thus gained. It then gradually proceeds by searching for principles of higher generality until it finally results in a universally applicable theory. Such a comprehensive, all-embracing scheme cannot be arrived at by inductive inference, but relies on abductive reasoning, which whitehead terms philosophic generalization. "In this description of philosophic method, the term philosophic generalisation' has meant 'the utilization of specific notions, applying to a restricted group of facts, for the divination of the generic notions which apply to all facts'." ${ }^{47}$

19 Whitehead is not entirely clear about the status of the final, adequate cosmology. Do we necessarily arrive at one single generalization, no matter if we choose psychology, religion, aesthetics or physics as a starting point? Does the temporal, processual nature of the universe ultimately undermine the systematic enterprise, because even the most abstract principles are incapable of capturing a continuously changing world? While in Process and Reality Whitehead tends to embrace the melioristic idea that progress in the formulation of ultimate generalities is possible, his later works suggest a much more careful optimism, re-verberating in the famous concluding remarks of his last lecture, namely that "exactness is a fake." 48 Although the topic is worth some detailed elaboration, for my present purpose it suffices to regard adequacy as a regulative ideal, which is to guard us against the different versions of biologism, physicalism or idealism, where the actual level of generality of the basic notions is overestimated.

One of the cornerstones of Whitehead's version of pragmatism is his interpretation of William James's epistemic conservatism, which is developed as one part of the rational side of his speculative philosophy. Here, the criterion of logic primarily refers to basic logical ideas, such as the law of non-contradiction and the principles of inference, while coherence, as in James, demands that the fundamental concepts not be isolated. Ignoring the psychological dimension of James' theory of truth, Whitehead particularly focuses on its epistemological and pragmatic aspect.

21 Whitehead defines coherence as meaning that "the fundamental ideas, in terms of which the scheme is developed, presuppose each other, so that in isolation they are meaningless." ${ }^{49}$ Other than in James, coherence is not primarily a subjective criterion that refers to a, not necessarily verbal, feeling that things fit, but is grounded in language. Coherence means a basic inventory of concepts whose fundamental notions form a nonhierarchical web and which cannot be understood in isolation. Each single term presupposes a systematic background that assigns to it a specific meaning as part of the system. Like in a puzzle, where the function of each single puzzle piece can only be deciphered in view of the complete picture, the meaning of each single notion results from its role as part of the whole. "The notion of the complete self-sufficiency of any item of finite knowledge is the fundamental error of dogmatism. Every such item derives its truth, and its very meaning, from its unanalyzed relevance to the background which is the unbounded universe." ${ }^{50}$ What could, in the vocabulary of the late Wittgenstein, be understood as the embeddedness in a Sprachspiel, is a never ending process aiming at the ideal of a completely defined metaphysical system. What we encounter in Whitehead's holistic coherentism, in contrast to James' epistemic conservatism, is the leapfrogging of a continuous genesis of individual propositions which are then gradually brought into coherence. Although the system lives on the data delivered by the sciences, human 
civilization and the history of philosophy, it is created as a systematic totality. Hence, by recourse to the intersubjective stock of different experiences the system blends out their subjective genesis without denying that experiences do have a history. It takes into account the experiences that have evolved over centuries and across cultures, but avoids the danger of having a particular starting point which regulates and potentially limits the discovery of further elements to be integrated into the coherent scheme.

The reliance on language in Whitehead's cosmology, however, is not absolute, and coherence is not a purely logical-analytical criterion, but to a certain extend entails a subjective component. On the one hand language as such is, by its very nature, underdetermined and unable to precisely capture the meaning of the fundamental notions, and on the other hand the relevant systematic background depends of the significance ascribed to it. In a philosophical cosmology, words and phrases that have their origin in the individual sciences or everyday language are forced to stand for a generality foreign to their genuine usage and "remain metaphors mutely appealing for an imaginative leap." ${ }^{11}$ Semantics may help us to avoid contradictoriness in our terminology, but the exact meaning of each notion in the specific context itself cannot be adequately expressed in words.

The epistemic holism advanced by whitehead also draws heavily on the pragmatic argument developed by James. Theoretically, a complete cosmology might explain all but one fact of human experience on the basis of its fundamental notions. This is precisely the case in what Whitehead identifies as a bifurcation of nature: Although the sciences have successfully managed to explain natural phenomena, their basic theoretical conceptions have turned out to be unable to do justice to human feelings and intentions. Instead of revising their theories, however, the sciences have tried to explain them away by either completely ignoring them or by regarding them as epiphenomena, making mutual critique among the sciences and commonsense impossible. Unless these notions form an integral part of the general scheme, however, it lacks coherence. The interdependency of the foundational theoretical notions is to prevent us from simply adding something to the scheme in order to explain an exception not covered by the scheme as such. The result is a metaphysical scheme that can account for all aspects of experience by fusing them into a coherent system.

\section{Religious Experience in James and Whitehead}

The different ideas of consistency and coherence in James and Whitehead do have practical consequences that can best be shown by reference to the phenomenon of religious experience. Among the factors relevant for the genesis of new experience in James' pragmatist thinking are not only empirical data, but also desires and emotions. ${ }^{52}$ Such emotions could, for example, appear in the form of religious doubts which may well influence an entire worldview. The starting point chosen for a coherent philosophy is thus essential for the resulting theory. "What we usually do is first to frame some system of concepts mentally classified, serialized, or connected in some intellectual way, and then to use this as a tally by which we 'keep tab' on the impressions that present themselves. ${ }^{\text {"53 }}$ As experiments occur successively and later theory formations take place in line with earlier ones, potential differences between individual sciences tend to become more pronounced in the course of time. The same holds true for the different fields of experience in individual people, where scientific knowledge might contradict the 
person's moral or religious convictions. Although philosophy aims at overcoming such gaps, James is aware that, psychologically, conservatism will largely determine how far such a gap can be bridged. Hence, he defends religious experience as one element of a holistic philosophical perspective, but does not conceive it as mandatorily required. In James, God's cash-value is put on trial by our previously accepted truths, but vice versa presents a challenge for scientific findings: "The truth of 'God' has to run the gauntlet of all our other truths. It is on trial by them and they on trial by it." ${ }^{54}$ For him, experiences are primarily individual and for those who have never had religious experience, there is no reason to integrate the hypothesis of God into the web of their truths. From the perspective of a religious person such a view might be deficient, but it fulfils the criteria of coherence and non-contradiction.

Whitehead, in contrast to James' focus on the genealogy of truths, demands that every single element of the entire texture of human experience be made a part of a coherent philosophical cosmology. Whitehead goes beyond James, although he sides him against Peirce's restrictive focus on the logic of science. His focus is on the "texture" ${ }^{55}$ of human experience in the sense of a cosmology which is not only coherent, but also adequate. The consequence is that the existence of religious experience as such must be counted among the integral aspects of a complete description of reality. As long as there are human beings who have religious experience it needs to be included in a coherent cosmology. Owing to a systematic approach that takes up Jamesian individual experience and transforms it into an objective datum, Whitehead's version of pragmatism is better suited than James's to arrive at what James himself considers to be an essential requirement of philosophy: "Philosophy must, in any case, complete the sciences, and must incorporate their methods. One cannot see why, if such a policy should appear advisable, philosophy might not end by foreswearing all dogmatism whatever, and become as hypothetical in her manners as the most empirical science of them all." ${ }^{\text {}}$ If "sciences" does not only refer to the natural sciences, but also the humanities, thus comprising every element of human experience, a philosophical cosmology needs to take account of all phenomena. It must not be left to the individual genesis of beliefs, nor must it be left to the fundamental assumptions that have evolved within a specific cultural environment. A philosophy that truly wants to mediate between religion, morality and the natural sciences will naturally develop into the holistic coherentism anticipated by James and advanced by Whitehead.

\section{Epilogue}

The development and transformation outlined above sheds light on the continuity of the pragmatist tradition. In the second half of the twentieth century, a number of philosophers have contributed to a revival of pragmatist thinking, the most significant and influential among them certainly being Willard van Orman Quine. In 1930, fascinated by the Principia Mathematica, Quine became a student of Whitehead, who also supervised his dissertation on The Logic of Sequences: A Generalization of Principia Mathematica. Not only does Quine inherit James' and Whitehead's project of refuting and overcoming "the supposed boundary between speculative metaphysics and natural science." ${ }^{57} \mathrm{He}$ also develops a holistic theory of truth closely related to the pragmatist programme of his predecessors. In repudiating the boundary between analytic and synthetic frameworks Quine approaches a holistic pragmatism that is obviously in line with James and Whitehead. "Each man is given a scientific heritage plus a continuing barrage of sensory 
stimulation; and the considerations which guide him in warping his scientific heritage to fit his continuing sensory promptings are, where rational, pragmatic." ${ }^{58}$ Novel findings are integrated into a scheme or theory based on a scientific heritage that we can imagine as being culturally and historically contingent. Whenever the sensory input delivers data inconsistent with the stock of previously acquired hypotheses, the heritage is warped, i.e. modified to better suit the data generated in the ongoing process of discovery. While, as in James, the individual is the epistemologically conservative element that owns the scientific heritage, the established conceptualizations are products of the social endeavour of science.

Equally indebted to the pragmatist approach sketched above is C. I. Lewis in his endeavour to test the acceptability of propositions in the framework of formal systems. While there can be different alternative formal frameworks that are all valuable instruments for reasoning, the best system, relative and absolute, proves itself on pragmatic grounds. A particular logical system is the appropriate instrument with regard to a certain range of application. The pragmatically most effective formal system is the one that entails the widest range of purposes, i.e. the system which allows for a formal verification of the widest scope of different propositions. ${ }^{59}$ Despite the narrow focus on logic and mathematics, Lewis shows that coherentism can be translated into a formally analyzable methodology in which propositions are verified within a formal system, while the system itself is tested against experience.

The list of pragmatists continuing the epistemological strand of pragmatism may certainly be extended to include such thinkers as Hilary Putnam, Juergen Habermas and Robert Brandom. What is most important, however, is that an analysis of the transformation of one aspect of pragmatist philosophy, namely its theory of truth, challenges the commonly accepted genealogy of pragmatism. The usual assumption is that pragmatism, anticipated by Ralph Waldo Emerson and American transcendentalism, was developed around the turn of the century by Peirce, James, Dewey and some of their disciples. It then fell into oblivion for a time of almost forty years, leaving a gap that, according to some interpreters, is even highlighted by the fact that none of the new pragmatists have devoted much time to a close examination of classical pragmatist positions.$^{60}$ Basically every work on the genealogy of pragmatism either implicitly or explicitly states that it was only after this gap that pragmatism was rediscovered and built upon by scholars as different as Willard V. O. Quine, Stanley Cavell and Richard Rorty. There can, of course, be no doubt as to counting all these authors among the pragmatists, although Quine himself did time and again appear to have turned against pragmatism. We should be aware of that fact, however, that there has never been a real temporal gap between classical pragmatism and contemporary neo-pragmatism. There was a continuous development from James to Quine and others through the philosophy of Whitehead, who left a form of pragmatism which on the one hand is closely related to James' thought and which on the other hand develops it into a philosophical theory much easier to approach from an analytic point of view. The attempt at turning classical pragmatism into a comprehensive theory which satisfies the demand for logical consistency has a long history that can be traced back to its very beginning. With Whitehead as the 'missing link,' the pragmatist tradition appears to have taken a rather linear development, while at the same time a Whiteheadian perspective on James' philosophy helps to shed light on some of the neglected and often underestimated details of his pragmatism. 


\section{BIBLIOGRAPHY}

BAUERLEIN M., (1997), The Pragmatic Mind, Durham/London, Duke University Press.

CHRISTENSEN D., (1994), “Conservatism in Epistemology,” Noûs, 28 (1), 69-89.

cоткіN G., (1985), "William James and the Cash-Value Metaphor," et cetera, 42 (1), 37-46.

EISENDRATH C. R., (1971), The Unifying Moment. The Psychological Philosophy of William James and Alfred North Whitehead, Cambridge, Harvard University Press.

JAMES W., (1975), Pragmatism, Burkhardt F., Bowers F., Skupskelis I. K. (eds.), The Works of William James, Cambridge, Harvard University Press.

JAMES W., (1975a), The Meaning of Truth, Burkhardt F., Bowers F., Skupskelis I. K. (eds.), The Works of William James, Cambridge, Harvard University Press.

JAMES W., (1976), Essays in Radical Empiricism, Burkhardt F., Bowers F., Skupskelis I. K., (eds.), The Works of William James, Cambridge, Harvard University Press.

JAMES W., (1977), A Pluralistic Universe, Burkhardt F., Bowers F., Skupskelis I. K., (eds.), The Works of William James, Cambridge, Harvard University Press.

JAMES W., (1979), Some Problems of Philosophy, Burkhardt F., Bowers F., Skupskelis I. K., (eds.), The Works of William James, Cambridge, Harvard University Press.

JAMES W., (1979a), The Will to Believe and Other Essays in Popular Philosophy, Burkhardt F., Bowers F., Skupskelis I. K., (eds.), The Works of William James, Cambridge, Harvard University Press.

JAMES W., (1981), Principles of Psychology, Vo. I-III, Burkhardt F., Bowers F., Skupskelis I. K., (eds.), The Works of William James, Cambridge, Harvard University Press.

JAMES W., (1985), Psychology. Briefer Course, Burkhardt F., Bowers F., Skupskelis I. K., (eds.), The Works of William James, Cambridge, Harvard University Press.

foley R., (1983), “Epistemic Conservatism,” Philosophical Studies, 43 (1), 165-82.

FUMERTON R., (2007), "Epistemic Conservatism: Theft or Honest Toil?," in Gendler T. \&

Hawthorne J. (eds.), Oxford Studies in Epistemology, Vol. 2, Oxford, Oxford University Press.

KANN Ch., (2001), Fußnoten zu Platon. Philosophiegeschichte bei A. N. Whitehead, Hamburg, Felix Meiner.

LEWIS C. I., (1956), Mind and the World Order. Outline of a Theory of Knowledge, New York, Dover Publications.

LOWE V., (1990), Alfred North Whitehead. The Man and His Work, Volume I: 1861-1910, Schneewind J. B., (ed.), Baltimore/London, John Hopkins University Press.

QUINE W. V. O., (1980), From a Logical Point of View, Cambridge, Harvard University Press.

RESCHER N., (2000), Realistic Pragmatism. An Introduction to Pragmatic Philosophy, Albany, State University of New York Press.

RORTY R., (1998), "Religious Faith, Intellectual Responsibility, and Romance," in Putnam R. A., (ed.), 1998, The Cambridge Companion to William James, Cambridge University Press, Cambridge. 
SINCLAIR S., (2009), “William James as American Plato?," William James Studies 4, 111-29.

WEBER M., (2002), “Whitehead's Reading of James and Its Context (Part One)," Streams of William

James, 4 (1), 18-22.

WEBER M., (2003), "Whitehead's Reading of James and Its Context (Part Two)," Streams of William

James, 5 (3), 26-31.

WEBER M., (2007), Whitehead's Pancreativism. The Basics, Frankfurt am Main, Ontos.

WHITEHEAD A. N., (1910-11), “Mathematics," Encyclopedia Britannica, Vol. 17, Cambridge, Cambridge University Press, 878-83.

WHITEHEAD A. N. (1956), Adventures of Ideas, New York, MacMillan.

WHITEHEAD A. N., (1967), Science and the Modern World, New York, The Free Press.

WHiteHEAD A. N., (1967a), The Aims of Education and Other Essays, New York, The Free Press.

WHITEHEAD A. N., (1968), Modes of Thought, New York, The Free Press.

WHITEHEAd A. N., (1968a), Essays in Science and Philosophy, New York, Greenwood Press.

WHITEHEAD A N., (1985), Process and Reality, Corrected Edition, Griffin D. R., Sherburne D. W., (ed.), New York, The Free Press.

WHITEHEAD A. N., (2005), Principle of Relativity, New York, Barnes and Noble Books.

\section{NOTES}

1. James (1975: 97).

2. James (1975a: 105).

3. Whitehead (1967: 143).

4. Lowe (1990: 345).

5. Whitehead (1910-11: 881).

6. Cited in Lowe (1990: 141).

7. Whitehead (1968: 2).

8. Whitehead (1956: 240).

9. Whitehead (1967: 50).

10. Lowe (1990: 345).

11. Sinclair (2009: 112).

12. Eisendrath (1971: xiii).

13. Weber 2002, and Weber 2003.

14. Sinclair 2009.

15. Sinclair (2009: 115).

16. Cf. Whitehead (1967a: 106f.).

17. Whitehead (1968: 106).

18. James (1975: 37).

19. James (1977: 140).

20. James (1981: 249).

21. James (1981: 961).

22. James (1975: 102).

23. James (1975a: 105).

24. Cf. Foley 1983, Christensen 1994, Fumerton 2007. 
25. Fumerton (2007: 63).

26. James (1975: 35$)$.

27. James (1975: 35).

28. James (1975: 35).

29. James himself, while usually speaking of "consistency" on one occasion also uses the notion of "coherence" with regard to the application of the pragmatic truth conception to past history (James 1975: 103).

30. James (1976: 135).

31. Cf. James (1976: 129).

32. James (1975a: 89).

33. James (1975: 98; emphasis added).

34. Rorty (1998: 85).

35. Rescher (2000: 18).

36. Rorty (1998: passim).

37. James (1975: 43).

38. The notion of cash-value is analyzed in more detail in a brilliant article by George Cotkin (1985).

39. James (1979a: 151).

40. Whitehead (1985: 3). See also Kann (2001: 100-12) and Weber (2007: 87-108).

41. Whitehead (1985: 3).

42. See the early reference to the necessity of a pragmatic approach in the sciences in Whitehead (2005: 60).

43. A thought that is also expressed in James (1985: 1): "Most thinkers have a faith at bottom there is but one science of all things, and that until all is known, no one thing can be completely known. Such a science, if realized, would be Philosophy."

44. Whitehead (1985: 13).

45. Whitehead (1985: 13).

46. Cf. Kann (2001: 110f).

47. Whitehead (1985: 5).

48. Whitehead (1968: 96).

49. Whitehead (1985: 3).

50. Whitehead (1968a: 100).

51. Whitehead (1985: 4).

52. Cf. James (1975: 35).

53. James (1975: 84)

54. James (1975: 56).

55. Whitehead (1985: 4).

56. James (1979: 19).

57. Quine (1980: 20).

58. Quine (1980: 46).

59. Cf. Lewis (1956: 32)

60. Cf. Bauerlein (1997: x). 


\section{ABSTRACTS}

The significance of A. N. Whitehead's contribution to 20th century metaphysics has become widely recognized. The focus on the novelty of his process ontology, however, has led to a view that isolates him from the mainstream of the tradition of Western philosophy. Hence, it is often overlooked that on the methodological level Whitehead is a pragmatist, whose much quoted indebtedness to William James is reflected in the project of his speculative metaphysics. A detailed analysis of the respective theories of truth and knowledge in James and whitehead illustrates their common methodological approach and allows us to assess the role of Whiteheadian thinking within the pragmatist tradition. James advances a form of epistemic conservatism that supplements the pragmatic idea of a concept's cash-value with the demand for internal consistency. New beliefs have to fit in the totality of all previously accepted convictions in order to become accepted as true. James argues his case on three levels - a psychological, an epistemological and a pragmatic one - and develops a theory of truth that comprises an empirical and a rational dimension. Whitehead takes up this two-sided approach, but modifies the idea of genetic consistency into that of systematic coherence. The fundamental concepts of an ontological theory must not be isolated from each other to allow for a cosmology which is both rational and satisfies the pragmatic test of applicability. With the close relation of James and Whitehead in mind, the latter can be identified as the 'missing link' that bridges the gap between the so-called classical pragmatism and its more analytic versions as advanced by Quine, Lewis and Rescher.

\section{AUTHOR}

\section{DENNIS SOELCH}

Heinrich Heine Universität Düsseldorf

Dennis.Soelch[at]uni-duesseldorf.de 